University of Wollongong

Research Online

Faculty of Engineering and Information

Faculty of Engineering and Information

Sciences - Papers: Part A

Sciences

$1-1-2014$

\title{
Environmental sustainability of soft soil improvement via vacuum and surcharge preloading
}

Cholachat Rujikiatkamjorn

University of Wollongong, cholacha@uow.edu.au

Buddhima Indraratna

University of Wollongong, indra@uow.edu.au

Follow this and additional works at: https://ro.uow.edu.au/eispapers

Part of the Engineering Commons, and the Science and Technology Studies Commons

Research Online is the open access institutional repository for the University of Wollongong. For further information contact the UOW Library: research-pubs@uow.edu.au 


\title{
Environmental sustainability of soft soil improvement via vacuum and surcharge preloading
}

\author{
Abstract \\ Due to environmental concerns, sustainable ground improvement is considered a critical part of modern \\ infrastructure development. Current policy on environmental sustainability often expects noise-free, \\ chemical-free, and low carbon emission processes, while being economical. In this context, the \\ application of prefabricated vertical drains (PVD) with vacuum preloading is regarded as one of the most \\ sustainable ground improvement techniques. Compared with other ground improvement methods such \\ as piling and chemical stabilization, this method will not only save a considerable cost in embankment \\ construction, but will also improve the construction rate of coastal highways and rail tracks and their load- \\ carrying capacity. The utilization of vacuum preloading will also minimize environmental impact by \\ reducing greenhouse gas emissions and the need for mining natural surcharge fill. The FEM code \\ ABAQUS with the equivalent approach is employed to study the performance of a full-scale test \\ embankment constructed in Thailand. A comparison of the performance of the vacuum system with the \\ standard surcharge fill is elucidated including its benefits and environmental impact.
}

\section{Keywords}

surcharge, preloading, via, vacuum, soil, improvement, environmental, sustainability, soft

\section{Disciplines}

Engineering | Science and Technology Studies

\section{Publication Details}

Rujikiatkamjorn, C. \& Indraratna, B. (2014). Environmental sustainability of soft soil improvement via vacuum and surcharge preloading. GEO-Congress 2014: Geo-Characterisation and Modeling for Sustainability (pp. 3658-3665). United States: American Society of Civil Engineers. 


\title{
Environmental Sustainability of Soft Soil Improvement via Vacuum and Surcharge Preloading
}

\author{
Cholachat Rujikiatkamjorn ${ }^{1}$ and Buddhima Indraratna ${ }^{2}$, F. ASCE
}

\begin{abstract}
${ }^{1}$ Associate Professor, Centre for Geomechanics and Railway Engineering, Faculty of Engineering, University of Wollongong, Wollongong City, NSW 2522, Australia, ARC Centre of Excellence in Geotechnical Science and Engineering, Australia ${ }^{2}$ Professor of Civil Engineering, Director, Centre for Geomechanics and Railway Engineering, Faculty of Engineering, University of Wollongong, Wollongong City, NSW 2522, Australia, ARC Centre of Excellence in Geotechnical Science and Engineering, Australia, email: indra@uow.edu.au
\end{abstract}

\begin{abstract}
Due to environmental concerns, sustainable ground improvement is considered a critical part of modern infrastructure development. Current policy on environmental sustainability often expects noise-free, chemical-free and low carbon emission processes, while being economical. In this context, the application of prefabricated vertical drains (PVD) with vacuum preloading is regarded as one of the most sustainable ground improvement techniques. Compared to other ground improvement methods such as piling and chemical stabilization, this method will not only save a considerable cost in embankment construction, but will also improve the construction rate of coastal highways and rail tracks and their load carrying capacity. The utilisation of vacuum preloading will also minimize an environment impact by lowering the greenhouse gas emission and the need for mining natural surcharge fill. The FEM code ABAQUS with the equivalent approach is employed to study the performance of a full-scale test embankment constructed in Thailand. A comparison of the performance of the vacuum system with the standard surcharge fill is elucidated including its benefits and environmental impact.
\end{abstract}

\section{INTRODUCTION}

Vacuum preloading with prefabricated vertical drains (PVDs) is one of the ground improvement techniques for soft clays with poor engineering characteristics (such as low shear strength, low permeability, high compressibility). The main aim of the application is to reduce soil consolidation period via reduced drainage path (Holtz et al., 1991). For vacuum application, it is expected that the applied vacuum pressure will propagate along the ground surface and down the drains, consolidating and strengthening the soil within the PVD stabilised zone (Chu et al. 2000; Rujikiatkamjorn et al 2007). Figure 1 presents the consolidation process of 
conventional method and vacuum-assisted preloading. The characteristics of vacuum preloading in comparison with conventional preloading are as follows: (a) Isotropic consolidation reduces the outward lateral movement; (b) The reduced embankment height via increase vacuum head results in higher embankment stability; (c) Unsatuaration around PVDs due to installation can be eliminated via vacuum application; and (d) The vacuum consolidation with PVDs is an environmentally friendly option. However, treatment of extracted groundwater may be required.

In this paper, factors affecting the vacuum system efficiency are described. The consolidation process accelerated by vacuum combined surcharge preloading with multi-drain is proposed using the equivalent plane strain approach. The finite element code (ABAQUS) with the equivalent approach is then used to analyse the performance of a full-scale test embankment constructed in Thailand. The numerical predictions are compared with the available field data. Carbon footprint from the vacuum consolidation technique is calculated and compared with other common soil stabilisation techniques.

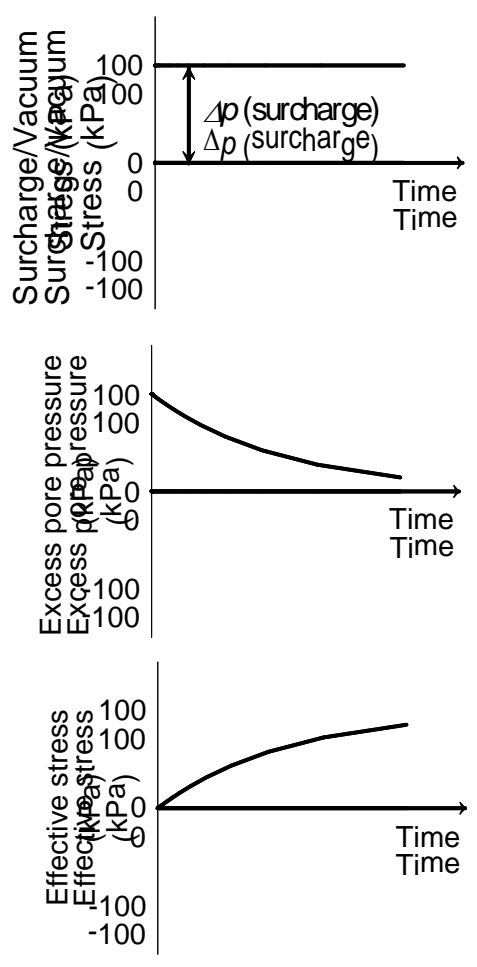

(a)
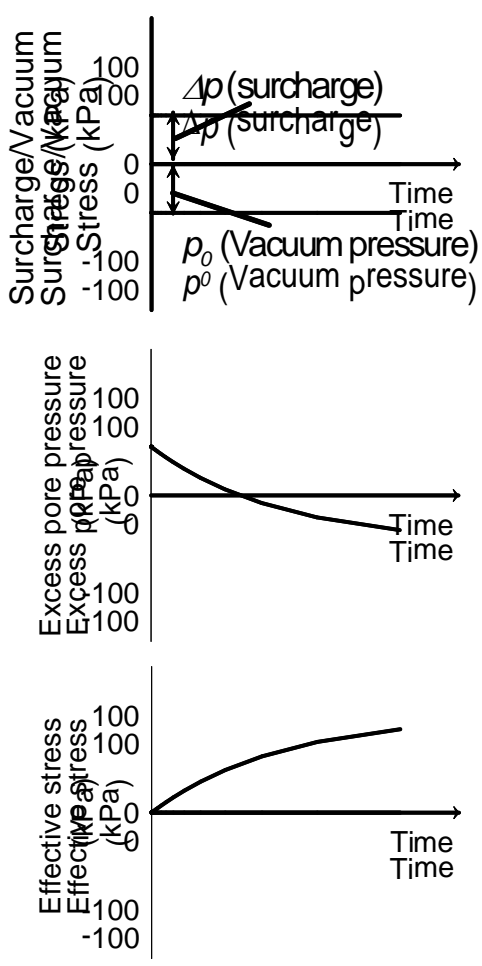

(b)

FIG. 1. Consolidation responses (a) conventional loading (b) vacuum preloading assuming no vacuum loss (adopted from Indraratna et al. 2005).

\section{COMPARISON WITH OTHER GROUND IMPROVEMENT TECHNIQUES}

In-situ installation of bored piles can make the soil and groundwater alkaline and driven piles create substantial noise levels as well as excessive lateral movements 
threatening adjacent utilities or structures. In the case of lime treatment, the soil and water $\mathrm{pH}$ can develop into highly alkaline $(\mathrm{pH}>10)$ and can adversely affect the native ecological system. Percolating of alkaline groundwater to nearby rivers can spoil aquaculture and natural fish habitats. The use of PVDs with vacuum preloading has no unfavorable effects on the environment compared to the above techniques and is also proven to be more economical than large-scale piling works. In a typical case, the treatment of extracted groundwater may be required before releasing to the nearby waterways, if the extracted water is excessively alkaline or acidic or has heavy metals. The cost of soil improvement by vacuum preloading can be reduced approximately 30 percent of that by conventional surcharge alone at Tianjin Port, China (Yan and Chu 2003). The vacuum system performance depends on: (a) integrity (airtight) of membrane, (b) effectiveness of the seal between the membrane edges and the ground surface, and (c) soil conditions and the location of ground water level (Cognon et al., 1994).

\section{IMPLICATION ON CARBON FOOTPRINT}

The Australian Government approved the Kyoto Protocol in 2008. Australia is committed to make sure its plan to control greenhouse emissions over the period 2008 to 2012. This has contributed to an increasing requirement to implement sustainable ground improvement techniques in both the private and public divisions. Carbon Footprint scheme has been proposed recently as a method to assess the amount of carbon dioxide $\left(\mathrm{CO}_{2}\right)$ from a particular activity is discharged to the environment. In this section, the Carbon Footprint method proposed by the Department of Climate Change (2008) was employed to calculate carbon emission from vacuum consolidation approach in comparison with pile installation.

Under the vacuum consolidation technique, the electricity used for vacuum pressure generation and vertical drain installation is about $4.33 \mathrm{Watts} / \mathrm{m}^{2}$ (Department of Climate Change, 2008). The carbon emission based electricity consumption can be calculated by:

$\mathrm{ECO}_{2}=$ Electricity energy $\times 1.31 / 1000$

where, $\mathrm{ECO}_{2}$ is carbon emission (ton) and the unit of Electricity is in kilowatt hour

For pile foundations, it is assumed that a $0.2 \mathrm{~m}$ diameter bored pile per $1 \mathrm{~m}^{2}$ is installed to meet the similar design criteria. The ratio of steel to concrete volume is approximately 0.1 . It is shown that $1.2 \mathrm{~kg}$ of $\mathrm{CO}_{2}$ is produced from $1 \mathrm{~kg}$ steel production and $0.16 \mathrm{~kg}$ of $\mathrm{CO}_{2}$ is released from $1 \mathrm{~kg}$ concrete production. Tables 1 and 2 present the amounts of carbon emission calculated from both schemes at three sites improved by vacuum consolidation. It can be seen that the carbon emission from vacuum technology is lesser than the pile foundations. This is because the production of concrete and steel requires significant levels of energy. In Australia, coal burning alone is more than $75 \%$ of total power generation. There is no doubt that vacuum consolidation is an environmentally friendly ground improvement for future projects. 
Table 1 Carbon Emission from vacuum consolidation

\begin{tabular}{|c|c|c|}
\hline Sites & $\begin{array}{c}\text { Duration of } \\
\text { vacuum } \\
\text { operation } \\
\text { (days) }\end{array}$ & Carbon Emission $\mathbf{( k g / \mathbf { m } ^ { 2 } )}$ \\
\hline $\begin{array}{c}\text { Suvarnabhumi Airport, } \\
\text { Thailand }\end{array}$ & 150 & 20.4 \\
(Indraratna et al. 2005) & 120 & 16.3 \\
\hline $\begin{array}{c}\text { Tianjin Port, China } \\
\text { (Rujikiatkamjorn et al 2008) }\end{array}$ & 300 & 40.9 \\
\hline $\begin{array}{c}\text { Ballina Bypass, Australia } \\
\text { (Indraratna et al. 2010) }\end{array}$ & & \\
\hline
\end{tabular}

Table 2 Carbon Emission from pile foundation

\begin{tabular}{|c|c|c|c|c|}
\hline Sites & $\begin{array}{c}\text { Pile length } \\
\text { (m) }\end{array}$ & $\begin{array}{c}\text { Concrete } \\
\text { (kg/pile) }\end{array}$ & Steel (kg/pile) & $\begin{array}{c}\text { Carbon } \\
\text { Emission } \\
\left(\mathbf{k g} / \mathbf{m}^{2}\right)\end{array}$ \\
\hline $\begin{array}{c}\text { Suvarnabhumi } \\
\text { Airport, } \\
\text { Thailand } \\
\text { (Indraratna et al. } \\
\text { 2005) }\end{array}$ & 15 & 1131 & 370 & 625 \\
\hline $\begin{array}{c}\text { Tianjin Port, } \\
\text { China } \\
\left(\begin{array}{c}\text { Rujikiatkamjorn } \\
\text { et al 2008) }\end{array}\right.\end{array}$ & 20 & 1508 & 493 & 833 \\
\hline $\begin{array}{c}\text { Ballina Bypass, } \\
\text { Australia } \\
\text { (Indraratna et al. } \\
\text { 2010) }\end{array}$ & 25 & 1885 & 617 & 1041 \\
\hline
\end{tabular}

\section{CONVERSION PROCEDURE FOR PLANE STRAIN FINITE ELEMENT ANALYSIS}

Indraratna and Redana (2000) and Indraratna et al. (2005) proposed the conversion procedures of the vertical drain system from axisymmetric to plane strain condition using the equivalent permeability coefficient of the soil in a unit cell. The width of the PVD $\left(2 b_{w}\right)$ and width of the disturbed zone $\left(2 b_{s}\right)$ are the same as their axisymmetric diameters $d_{s}$ and $d_{w}$, respectively (i.e. $b_{w}=d_{w} / 2$ and $b_{s}=d_{s} / 2$ ) (Fig. 2).

A relationship between equivalent permeability in undisturbed and smear zone ( $k_{h p}$ and $k_{s p}$ ) is as follows (Indraratna et al. 2005): 


$$
\begin{aligned}
& \frac{k_{s p}}{k_{h p}}=\frac{\beta}{\frac{k_{h p}}{k_{h}}\left[\ln \left(\frac{n}{s}\right)+\left(\frac{k_{h}}{k_{s}}\right) \ln (s)-0.75\right]-\alpha} \\
& \mu_{p}=\left[\alpha+(\beta) \frac{k_{h p}}{k_{h p}^{\prime}}\right] \\
& \alpha=\frac{2}{3}-\frac{2 b_{s}}{B}\left(1-\frac{b_{s}}{B}+\frac{b_{s}^{2}}{3 B^{2}}\right) \\
& \beta=\frac{1}{B^{2}}\left(b_{s}-b_{w}\right)^{2}+\frac{b_{s}}{3 B^{3}}\left(3 b_{w}^{2}-b_{s}^{2}\right)
\end{aligned}
$$

where, $d_{s}, d_{w}$ and $d_{e}$ are the smear zone diameter, PVD equivalent diameter and PVD influence zone diameter, respectively. $k_{h}$ and $k_{s}$ are vertical permeability and horizontal soil permeability for undisturbed and smear zone in axisymmetric condition, respectively.
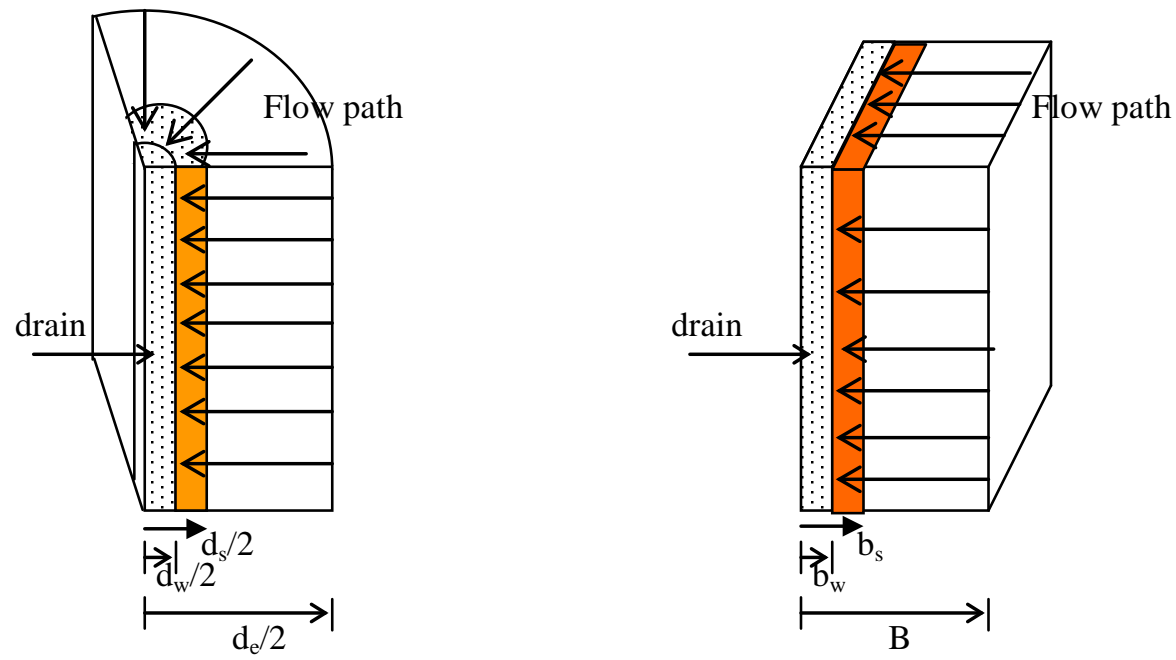

FIG. 2 Unit cell for conversion from axisymmetric to plane strain

If smear effect is negligible, in the above expression the ratio of plane strain to axisymmetric permeability can be obtained, as also proposed earlier by Hird et al. (1992), as follows:

$$
\frac{k_{h p}}{k_{h}}=\frac{0.67}{[\ln (n)-0.75]}
$$




\section{APPLICATION TO A CASE HISTORY}

The Suvarnabhumi International Airport is approximately $30 \mathrm{~km}$ from Bangkok, Thailand. The geological profile is considered as a thick low-permeability soft clay up to $20 \mathrm{~m}$ deep. Ground improvement techniques are necessary before the airport construction to prevent excessive long term settlement and improve the soil shear strength. Several trial embankments were constructed, one of them (TV1) was improved by PVDs and vacuum application due to the lack of good quality of surcharge fill. The vacuum with membrane system equivalent to $140 \mathrm{kPa}$ surcharge pressure was adopted with $15 \mathrm{~m}$ long PVDs and $0.3 \mathrm{~m}$ thick sand blanket. Indraratna et al. (2005) examined the consolidation behaviour via the finite element code, ABAQUS (Hibbitt, Karlsson, and Sorensen, 2004). The proposed equivalent plane strain formulation (Equations 2-6) with the modified Cam-clay theory was employed in the analysis. The constant values of undisturbed to disturbed permeability ratio $\left(k_{h} / k_{s}\right)$ and smear zone extent $\left(d_{s} / d_{w}\right)$ were assumed to be 2 and 6 , respectively. The finite element mesh is shown in Fig. 3.

The predicted and measured vertical displacements, excess pore pressures and horizontal displacements for embankments TV1 are shown in Fig. 4. Overall the numerical results with proposed conversion procedure are in agreement with the measured results. Excess pore pressure from the vacuum application is considerably less than that from the surcharge only case, which allows the rate of construction of a vacuum-assisted embankment to be higher than construction with surcharge load alone. This can also be observed the yielded lateral displacement. It was estimated the consolidation time with vacuum application can be shortened by 4 months.

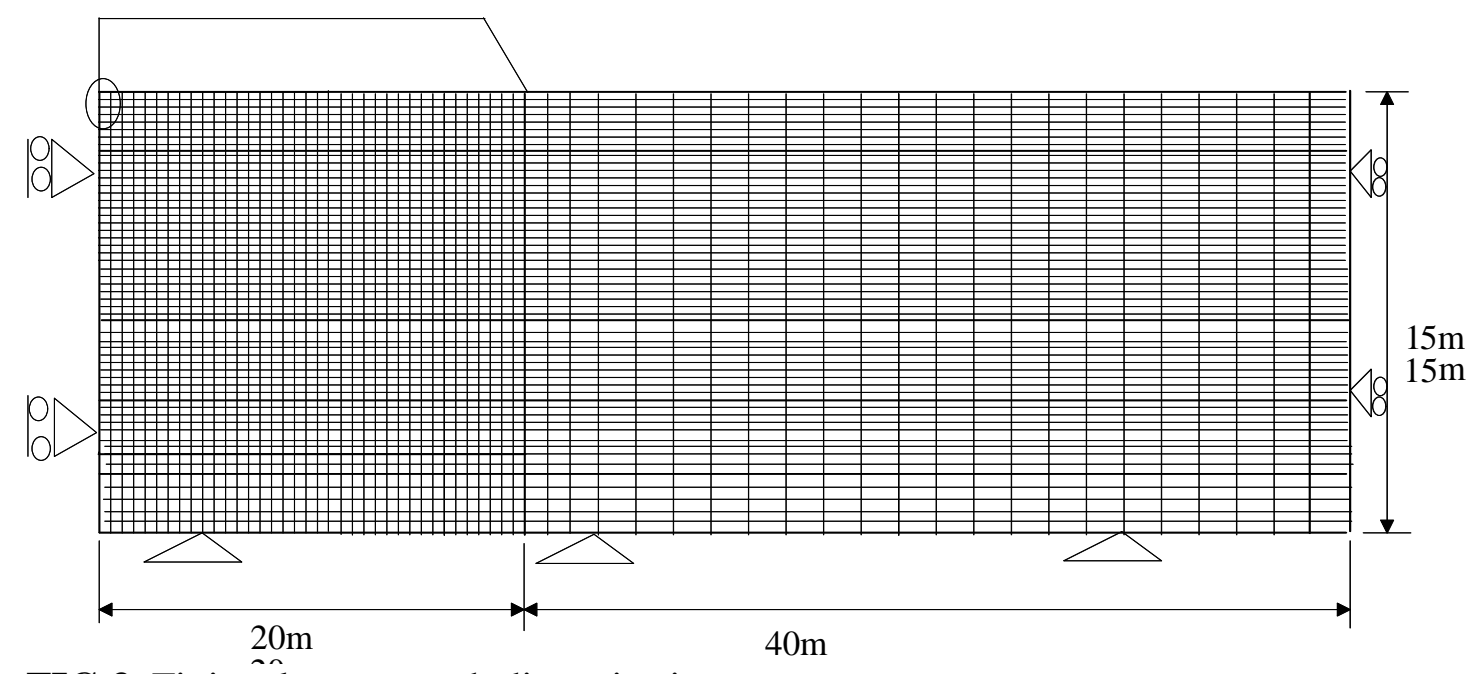

FIG 3. Finite element mesh discretisation 

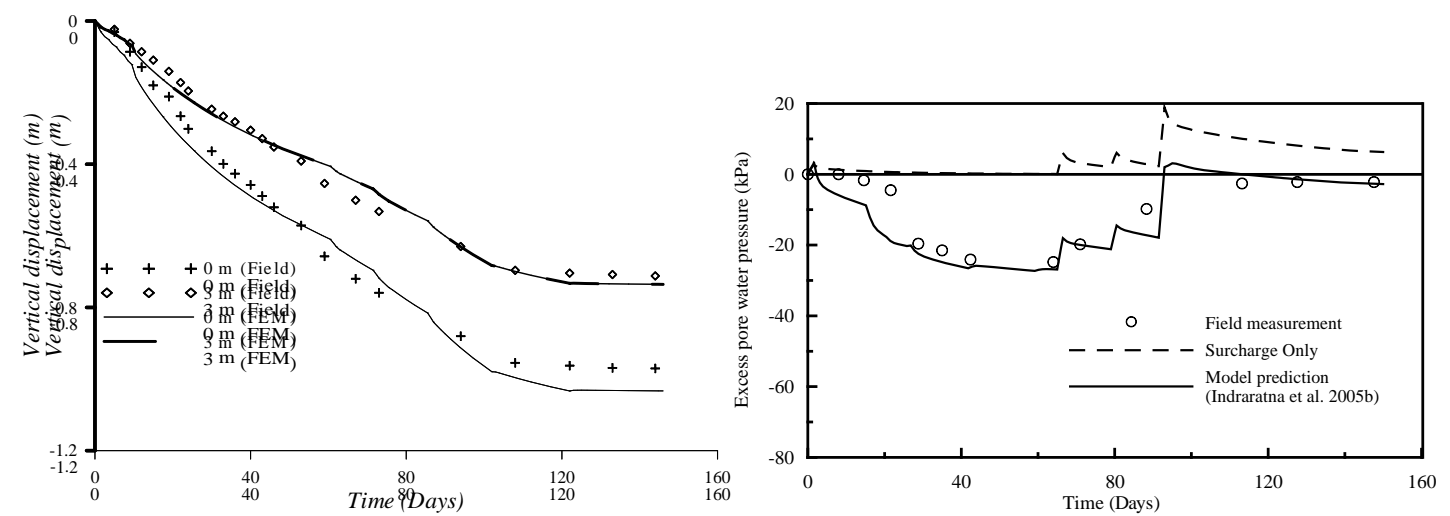

(a)

(b)

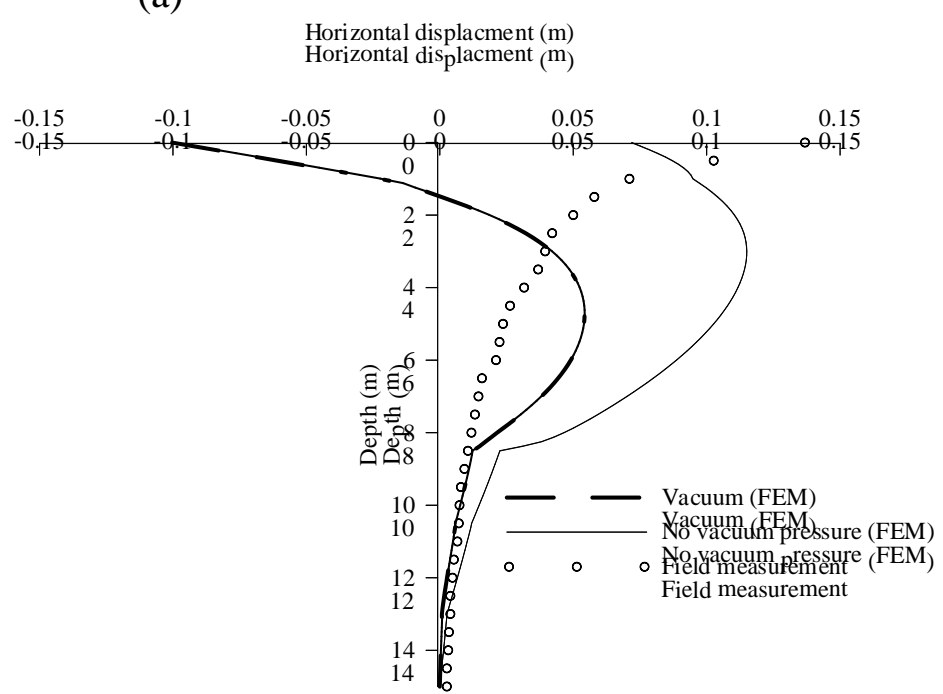

(c)

FIG. 4. Embankment TV1 (a) settlements, (b) excess pore pressures, and (c) lateral displacement (data from Indraratna et al. 2005).

\section{CONCLUSIONS}

The sustainable ground improvement techniques have been increasingly supported to minimize the environmental degradation all over the world. The significance of carbon footprint in infrastructure development has to be considered as a major issue. In ground improvement schemes, the materials used can be one of the most vital factors in determining the carbon footprint. In this study, vacuum consolidation can be considered as a sustainable ground improvement technique without compromising quality, cost and time. The carbon discharged due to pile foundations is about 30 times that by vacuum system with PVD. Therefore,

A system of vertical drains combined with vacuum preloading is an effective method for accelerating soil consolidation. An analytical model for consolidation under plane strain condition has been proposed and compared field measurements. Multi-drain analysis of a case history from Thailand was analyzed using finite element code via the conversion procedure. It can be seen that consolidation time via vacuum application can be reduced and multi-stage construction can be avoided. The inward lateral displacement can be controlled, thus increasing embankment stability. 


\section{ACKNOWLEDGMENTS}

More elaborate details of the contents discussed in this paper can be found in previous publications of the first author and his research students in ASCE and Canadian Geotechnical Journals, since mid 1990’s.

\section{REFERENCES}

Chu, J., Yan, S.W. and Yang, H. 2000. 'Soil improvement by the vacuum preloading method for an oil storage station'. Geotechnique, 50(6): 625-632.

Cognon, J. M., Juran, I and Thevanayagam, S., 1994. 'Vacuum consolidation technology- principles and field experience, Proceedings of conference on vertical and horizontal deformations of foundations and embankments deformations', College station, Texas.

Department of Climate Change 2008. 'National Greenhouse and Energy Reporting (Measurement) Determination’, 216p.

Holtz R.D., Jamiolkowski M.B., Lancellotta R., and Pedroni R. 1991. 'Prefabricated Vertical Drains: Design and Performance’. CIRIA: London; 1-131.

Hibbitt, Karlsson, and Sorensen (2004) 'ABAQUS/Standard User's Manual,' Published by HKS Inc.

Indraratna, B., and Redana, I. W. 1998. 'Laboratory determination of smear zone due to vertical drain installation’. J. Geotech. Eng., ASCE, Vol. 125 No. 1, pp. 96-99.

Indraratna, B., Rujikiatkamjorn, C., Kelly, R. and Buys, H. 2010 'Environmentally Sustainable Soft Soil Improvement via Vacuum and Surcharge Preloading.' Ground Improvement 163 (1), 31-42.

Indraratna, B., Sathananthan, I., Rujikiatkamjorn, C. and Balasubramaniam, A.S. 2005. 'Analytical and Numerical Modelling of Soft Soil Stabilised by PVD incorporating Vacuum Preloading.' International Journal of Geomechanics, ASCE Vol. 5 No. 2, pp. 114-124.

Rujikiatkamjorn C., Indraratna, B. and Chu, J. 2007. 'Numerical modelling of soft soil stabilized by vertical drains, combining surcharge and vacuum preloading for a storage yard.' Canadian Geotechnical Journal, Vol. 44, pp. 326-342.

Rujikiatkamjorn C., Indraratna, B. and Chu, J. (2008). '2D and 3D Numerical Modeling of Combined Surcharge and Vacuum Preloading with Vertical Drains.' International Journal of Geomechanics, ASCE, 8(2), 144-156.

Yan, S.W. and Chu, J. 2003. 'Soil improvement for a road using a vacuum preloading method.’ Ground Improvement, 7(4): 165-172. 